\title{
Identifikasi Bakteri dengan Menggunakan Metode Pewarnaan Gram pada Sputum Pasien Batuk Berdahak di Puskesmas Bahu Manado Periode Agustus-Desember 2018
}

\author{
${ }^{1}$ Peter J. A. Koleangan \\ ${ }^{2}$ John Porotu'o \\ ${ }^{2}$ Linda Tompodung
}

\author{
${ }^{1}$ Program Studi Pendidikan Dokter Fakultas Kedokteran Universitas Sam Ratulangi Manado \\ ${ }^{2}$ Bagian Mikrobiologi Fakultas Kedokteran Universitas Sam Ratulangi Manado \\ Email: 15011101031@student.unsrat.ac.id
}

\begin{abstract}
Disease with productive cough symptomp is contagious, therefore, it is commonly found in the society, varies from mild to severe stages. Cases of productive cough, that is a respiratory tract infection, is one of the 10 most common diseases at Bahu Health Center. Identification of bacteria can be performed with Gram staining, so it will lead to make better and more precise treatment. This study was aimed to identify the bacteria in the sputum of productive cough patients at Bahu Health Center by using Gram staining method. This was a descriptive study with a cross sectional design. The results showed that Streptococcus bacteria were the most common (50\%) compared to Diplococcus bacteria (15\%). Conclusion: In the sputum of patients with productive cough, the most common type of bacteria was Streptococcus.
\end{abstract}

Keywords: bacteria, productive cough, respiratory tract infection

\begin{abstract}
Abstrak: Penyakit dengan gejala batuk berdahak bersifat menular sehingga sering dijumpai di masyarakat dari manifestasi ringan sampai berat. Kasus yang berhubungan dengan batuk berdahak seperti infeksi saluran pernapasan merupakan salah satu dari 10 penyakit utama di Puskesmas Bahu. Dengan metode pewarnaan Gram, hasil identifikasi dapat membuat penatalaksanaan menjadi lebih cepat dan tepat. Penelitian ini bertujuan ntuk mengidentifikasi bakteri dengan menggunakan metode pewarnaan Gram pada sputum pasien yang memiliki keluhan batuk di Puskesmas Bahu Manado. Jenis penelitian ialah deskriptif dengan desain potong lintang. Hasil penelitian mendapatkan bakteri dengan morfologi Streptococcus yang terbanyak (50\%) dibandingkan bakteri dengan morfologi Diplococcus (15\%). Simpulan: Pada sputum pasien batuk berdahak yang terbanyak ditemukan ialah bakteri Streptcoccous.
\end{abstract}

Kata kunci: bakteri, batuk berdahak, infeksi saluran napas

Batuk merupakan mekanisme pertahanan tubuh untuk mengeluarkan bahan iritan dari saluran napas. Contoh bahan iritan yang dapat menjadi pemicu batuk yaitu mikroorganisme. Mikroorganisme yang dapat menyebabkan infeksi saluran pernapasan ialah bakteri, virus, dan jamur. $^{1}$

Batuk dapat menularkan mikroorganisme patogen melalui udara. Karena batuk dapat dengan mudah menularkan mikro- organisme patogen, hal ini membuat gejala batuk sebagai salah satu gejala yang paling sering dikeluhkan oleh masyarakat. Mikroorganisme yang disebar oleh batuk dapat menginfeksi siapa saja baik bayi, anakanak, remaja, orang dewasa, dan lanjut usia. $^{2}$

Berdasarkan data WHO, salah satu penyakit yang menyebabkan batuk berdahak, yaitu pneumonia, memiliki persentase 
sebesar $16 \%$ terhadap kematian anak-anak di bawah 5 tahun di seluruh dunia. ${ }^{3}$ Pneumonia dapat disebabkan oleh infeksi mikroorganisme seperti jamur, virus, atau bakteri. Pneumonia yang disebabkan oleh infeksi bakteri dapat ditatalaksana dengan pemberian antibiotik. ${ }^{3}$

Untuk negara berkembang, infeksi saluran pernapasan akut (ISPA), merupakan salah satu kasus yang paling banyak terjadi. Pada tahun 2012, kasus ISPA terbanyak terjadi di India sebanyak 43 juta kasus, Tiongkok 21 juta kasus, Pakistan 10 juta kasus, dan Bangladesh, Nigeria, Indonesia, masing-masing 6 juta kasus. ${ }^{4}$

Di Indonesia, penyakit dengan keluhan batuk memiliki prevalensi sebesar $15 \%$ pada anak-anak, dan $20 \%$ pada orang dewasa. $^{2}$ Keluhan ISPA memiliki persentase sekitar 40\%-60\% sebagai alasan pasien berkunjung ke Puskesmas, dan 15\%-35\% untuk kunjungan ke rumah sakit. ${ }^{4}$

Di Sulawesi Utara, perkiraan persentase kasus pneumonia pada balita senilai 2,68\% pada tahun 2016. ${ }^{5}$ Hasil yang sama juga didapatkan pada tahun 2017. Nilai persentase tersebut masih berada di bawah rerata nasional yaitu $3,55 \%{ }^{6}$

Untuk kasus ISPA pada tahun 2016 paling banyak ditemukan di Manado dengan 3.476 penderita. Tahun 2017, kasus pneumonia pada balita yang ditemukan di seluruh puskesmas di Kota Manado berjumlah 906 penderita, dan penderita yang ditemukan dan ditangani berjumlah 285 penderita. $^{7}$

Untuk kejadian infeksi saluran napas di Puskesmas Bahu Manado pada tahun 2009 berjumlah 266 kasus, dan menempati urutan pertama dari 5 penyakit utama di Puskesmas Bahu Manado. Pada tahun 2011, kasus infeksi saluran napas masih menempati urutan pertama dari 10 penyakit utama. $^{8}$

Penatalaksanaan untuk infeksi saluran napas bisa dilakukan dengan cepat dan tepat apabila mikroorganisme yang menjadi penyebab dapat teridentifikasi. Untuk mikroorganisme jenis bakteri, salah satu metode identifikasi yang dapat dilakukan ialah dengan pewarnaan Gram dan bakteri dapat teridentifikasi sesuai kategorinya di Gram positif atau Gram negatif. ${ }^{9}$

Penelitian ini bertujuan untuk melakukan identifikasi bakteri yang menyebabkan batuk dengan metode pewarnaan Gram sebagai salah satu cara untuk mengidentifikasi di Puskesmas Bahu Manado. Hasil dari identifikasi dapat digunakan sebagai panduan untuk memberikan terapi antibiotik yang tepat.

\section{METODE PENELITIAN}

Penelitian ini menggunakan metode deskriptif dengan desain potog lintang untuk menentukan ada tidaknya bakteri dari sputum penderita batuk di Puskesmas Bahu Manado. Penelitian ini melibatkan 20 subyek yang memiliki keluhan batuk berdahak. Setelah mendapatkan persetujuan dari subyek penelitian, peneliti mengambil sampel sputum dengan menggunakan pot sputum yang sudah disterilkan terlebih dahulu.

\section{HASIL PENELITIAN}

Hasil penelitian mendapatkan distribusi subyek penelitian berdasarkan jenis kelamin terbanyak pada perempuan yaitu sebanyak 11 kasus (55\%), dibandingkan dengan laki-laki yaitu sebanyak 9 kasus (45\%). Tabel 1 menunjukkan distribusi sampel penelitian berdasarkan kelompok usia dan jenis kelamin. Didapatkan terbanyak pada kelompok usia manula lakilaki yaitu sebanyak 4 orang (20\%), diikuti dengan kelompok usia remaja akhir perempuan yaitu sebanyak 3 orang (15\%).

Tabel 2 memperlihatkan hasil pewarnaan Gram positif paling banyak ditemukan dengan jumlah keseluruhan 17 sampel, dimana 10 sampel menunjukkan hasil pewarnaan Gram positif dan 7 sampel meunjukkan hasil pewarnaan campuran antara Gram positif dan Gram negatif.

Tabel 3 menunjukkan jenis infeksi bakteri yang paling banyak ditemukan adalah infeksi bakteri Streptococcus yang ditemukan pada 10 pasien $(50 \%)$, dan paling sedikit adalah infeksi bakteri Diplococcus yang ditemukan pada 3 (15\%) pasien. 
Tabel 1. Distribusi sampel dengan keluhan batuk berdasarkan kelompok usia dan jenis kelamin di Puskesmas Bahu Manado

\begin{tabular}{lccc}
\hline \multicolumn{1}{c}{ Kelompok usia } & Jenis kelamin & N & \% \\
\hline Balita (0-5 tahun) & Laki-laki & 0 & 0 \\
& Perempuan & 0 & 0 \\
Kanak-kanak (6-11 tahun) & Laki-laki & 0 & 0 \\
& Perempuan & 0 & 0 \\
Remaja awal (12-16 tahun) & Laki-laki & 0 & 0 \\
& Perempuan & 0 & 0 \\
Remaja akhir (17-25 tahun) & Laki-laki & 2 & 10 \\
& Perempuan & 3 & 15 \\
Dewasa awal (26-35 tahun) & Laki-laki & 0 & 0 \\
& Perempuan & 2 & 10 \\
Dewasa akhir (36-45 tahun) & Laki-laki & 1 & 5 \\
& Perempuan & 2 & 10 \\
Lansia awal (46-55 tahun) & Laki-laki & 1 & 5 \\
Lansia akhir (56-65 tahun) & Perempuan & 2 & 10 \\
& Laki-laki & 0 & 0 \\
Manula (>65 tahun) & Perempuan & 1 & 5 \\
& Laki-laki & 4 & 20 \\
& Perempuan & 2 & 10 \\
\hline
\end{tabular}

Tabel 2. Hasil pewarnaan Gram pada pasien dengan keluhan batuk berdahak di Puskesmas Bahu Manado

\begin{tabular}{lcc}
\hline \multicolumn{1}{c}{ Hasil pewarnaan } & N & \% \\
\hline Gram positif & 10 & 50 \\
Gram negatif & 3 & 15 \\
Gram positif dan negatif & 7 & 35 \\
Total & 20 & 100 \\
\hline
\end{tabular}

Tabel 3. Jenis infeksi bakteri pada pasien dengan keluhan batuk berdahak di Puskesmas Bahu Manado

\begin{tabular}{lcc}
\hline Jenis bakteri & N & \% \\
\hline Streptococcus & 10 & 50 \\
Diplococcus & 3 & 15 \\
Infeksi campuran & 7 & 35 \\
\hline
\end{tabular}

\section{BAHASAN}

Penelitian ini dilakukan terhadap pasien dengan keluhan batuk berdahak di Puskesmas Bahu Manado. Jumlah pasien dengan keluhan batuk berdahak yang berobat ke Puskesmas Bahu Manado dalam periode pengambilan sampel penelitian ini sebanyak 20 orang. Jumlah ini lebih sedikit dari penelitian serupa yang dilakukan sebelumnya oleh Serviyanti et al. ${ }^{8}$ di Puskesmas Bahu Manado dengan waktu penelitian yang lebih panjang, yaitu periode November 2012 sampai Januari 2013 sebanyak 30 sampel.

Mengenai distribusi subyek berdasarkan jenis kelamin, didapatkan pasien dengan keluhan batuk berdahak terbanyak terdapat pada perempuan, yaitu 11 dari total 20 subyek penelitian. Hal ini sejalan dengan penelitian yang dilakukan oleh Marrie dan Huang. ${ }^{10}$ yang melaporkan bahwa pasien yang terkena infeksi saluran napas bawah lebih banyak pada perempuan (52\%) dibandingkan laki-laki (48\%). Hal ini dapat disebabkan karena perempuan cenderung untuk memeriksakan diri ke pelayanan kesehatan dibandingkan lakilaki, walaupun penyakit yang diderita masih dalam fase akut. ${ }^{11}$

Mengenai distribusi subyek menurut kelompok usia dan jenis kelamin, didapatkan pasien yang paling banyak datang dengan keluhan batuk berdahak ialah kelompok usia di atas 65 tahun (Tabel 1). Hal ini sesuai dengan penelitian yang dilakukan oleh Janssens et al $^{12}$ yang mendapatkan prevalensi pneumonia paling banyak ditemukan pada kelompok usia manula dengan estimasi 22-45 kasus per 1000 orang.

Kasus infeksi saluran pernapasan paling banyak didapatkan pada kelompok usia manula. Hal ini disebabkan karena 
pada usia tua terjadi peningkatan risiko infeksi saluran pernapasan yang diakibatkan oleh penurunan daya tahan tubuh, penurunan kekuatan otot-otot yang menunjang pernapasan, perubahan lapisan mukosa saluran pernapasan, dan faktor predisposisi lainnya seperti pada pasien dengan riwayat stroke yang memiliki gangguan dalam proses menelan makanan, dapat terjadi pneumonia aspirasi. ${ }^{13}$

Berdasarkan pengelompokan dari hasil pewarnaan Gram (Tabel 2), bakteri Gram positif paling banyak ditemukan, yaitu pada 17 sampel sputum; 10 sampel menunjukkan hasil pewarnaan Gram positif dan 7 sampel meunjukkan hasil pewarnaan campuran antara Gram positif dan Gram negatif. Hasil yang didapatkan sesuai dengan Khan et al. ${ }^{14}$ yang mendapatkan bahwa bakteri Gram positif yang paling banyak menjadi penyebab infeksi saluran napas bawah. Hal tersebut diakibatkan karena beberapa jenis bakteri Gram positif merupakan flora normal paru seperti bakteri Streptococcus pneumniae atau Streptococcus grup A. ${ }^{14}$

Berdasarkan hasil pemeriksaan dari 20 sampel sputum yang diteliti, kesemuanya menunjukkan adanya bakteri. Bakteri yang didapatkan antara lain bakteri dengan morfologi streptococcus pada 17 sampel dan bakteri dengan morfologi diplococcus pada 10 sampel (Tabel 3). Hasil yang didapatkan selaras dengan penelitian yang dilakukan sebelumnya oleh Servyanti et al. ${ }^{8}$ di Puskesmas Bahu Manado yang melaporkan streptococcus sebagai bakteri yang paling banyak ditemukan dengan jumlah 8 sampel dari total 30 sampel.

Jenis bakteri yang ditemukan berdasarkan hasil pemeriksaan dari 20 sampel sputum ialah Streptococcus pada 10 sampel, kemudian campuran bakteri Streptococcus dan diplococcus pada 7 sampel, dan diplocococcus saja pada 3 sampel. Bakteri streptococcus merupakan bakteri yang paling banyak menyebabkan pneumonia. Hal tersebut sesuai dengan penelitian yang dilakukan oleh Cilloniz et al. ${ }^{15}$ yang mendapatkan Streptococcus pneumoniae sebagai bakteri penyebab infeksi saluran napas bawah terbanyak dengan jumlah 56 sampel dari total 514 sampel.

Bakteri Streptococcus pneumoniae merupakan bakteri flora normal dalam saluran napas manusia. Bakteri ini dapat menjadi patogen pada pasien dengan daya tahan tubuh menurun akibat usia lanjut, atau kondisi fisik dan medis lainnya. ${ }^{16} \mathrm{Hal}$ yang perlu diperhatikan dari temuan bakteri Streptococcus pneumonia ialah morfologi dari bakteri tersebut dapat ditemukan dalam bentuk lanset shaped diplococci. ${ }^{17}$ Namun bakteri diplococcus juga dapat menjadi penanda infeksi bakteri seperti Moraxella catarrhalis, ${ }^{18}$ Neisseria gonorrhoeae, ${ }^{19}$ dan Neisseria meningitidis ${ }^{20}$. Untuk menentukan bakteri dengan morfologi diplococcus yang dapat menjadi penyebab spesifik batuk berdahak perlu dilakukan pemeriksaan lebih lanjut.

\section{SIMPULAN}

Berdasarkan hasil penelitian ini dapat disimpulkan bahwa pasien dengan keluhan batuk berdahak terbanyak berdasarkan jenis kelamin ialah perempuan. Hasil identifikasi bakteri menggunakan teknik pewarnaan Gram menunjukkan yang terbanyak ialah streptococcus.

\section{SARAN}

Disarankan menggunakan waktu penelitian yang lebih panjang mengingat jumlah sampel yang didapatkan belum maksimal. Untuk penelitian selanjutnya disarankan agar dapat menambah beberapa variabel yang dapat menjadi faktor risiko seperti merokok, pekerjaan, kondisi lingkungan, riwayat penyakit dahulu, dan pendidikan.

\section{DAFTAR PUSTAKA}

1. Sherwood L. Fisiologi Manusia dari Sel ke Sistem (6th ed). Yesdelita N, editor. Jakarta: EGC, 2007.

2. Saminan S. Nilai spirometri penderita batuk setelah minum. Jurnal Kedokteran Yarsi. 2015;23(1):028-34.

3. WHO. www.who.int. [Online]. 2016 [cited 2018 Nov 19]. Available from: http://www.who.int/news-room/factsheets/detail/pneumonia.II

4. Direktorat Jendral Pengendalian Penyakit dan 
Penyehatan Lingkungan. Pedoman Tatalaksana ISPA. Jakarta: Kementerian Kesehatan Republik Indonesia, Departemen Kesehatan, 2012.

5. Kementerian Kesehatan Republik Indonesia. Profil Kesehatan Indonesia 2016. Jakarta: Departemen Kesehatan, 2017.

6. Kementerian Kesehatan Republik Indonesia. Profil Kesehatan Indonesia Tahun 2017. Jakarta: Departemen Kesehatan, 2018.

7. Dinas Kesehatan Daerah Provinsi Sulawesi Utara. Profil kesehatan sulawesi utara. Laporan Profil Kesehatan. Manado:, Dinas Kesehatan; 2016.

8. Serviyanti I, Soeliongan S, Kountul C. Pola bakteri dari sputum penderita infeksi saluran pernapasan di puskesmas bahu. eBm. 2013;1(1)325-9.

9. Hall GG. Medical Bacteriology. I: Bluth MH, Bock JL, Bowne WB, Htuchison RE, Karcher DS, Lifshitz MS et al, editors. Henry's Clinical Diagnosis and Management by Laboratory Methods ( 23rd ed). St. Louis, Missouri: Elsevier, 2017; p. 1114-52.

10. Marrie TJ, Huang JQ. Low-risk patients admitted with community-acquired. Am J Med. 2005;118(12):1357-63.

11. Wisser O, Vaupel JW. The sex differential in mortality: a historical comparison of the adult-age pattern of the ratio and the difference. MPIDR Working Paper. WP 2014-005. Rostock: Max Planck Institute for Demographic Research, 2014.

12. Janssens JP, Krause KH. Pneumonia in the very old. Lancet Infect Dis. 2004 February; 4(2).
13. WHO. Infeksi saluran pernapasan akut (ISPA). Geneva: WHO, 2007.

14. Sliedrecht A, van Elzen WPJ, Verheij TJM, Westendorp RGJ, Gussekloo J. Incidence and predictive factors of lower respiratory tract infections among the very elderly in the general population. Thorax. 2008;63(9):817-22.

15. Cilloniz C, Albert LA, Gabarrus A, Rangel E, Bello S, Marco F, et al. The effect of macrolide resistance on the presentation and outcome of patients hospitalized for Streptococcus pneumoniae Pneumonia. Am J Respir Crit Care Med. 2015;191(11):1265-72.

16. Van de Beek D, de Gans J, Tunkel AR, Wijdicks EFM. Community-acquired bacterial meningitis in adults. NEJM. 2006;354(1):44-53.

17. Smith B, Hill J. Reading and reporting Gram stained direct smears (Online CE Course). 2018. [cited 2018 Dec 13]. Available from: https://www.labce. com/reading-gram-stained-directsmears.aspx.

18. Murphy TF, Parameswaran GI. Moraxella catarrhalis, a Human Respiratory Tract Pathogen. Clin Infect Dis. 2009; 49(1):124-31.

19. Naheed N, Alam M, Lutwick LI. Gramnegative diplococcal respiratory infections. Current Infectious Disease Reports. 2003;5(3):238-45.

20. Romero-Gomez MP, Rentero Z, Paño JR, Mingorance J. Bacteraemic pneumonia caused by Neisseria meningitidis serogroup Y. Respir Med Case Rep. 2011;5:23-24. 